NBER WORKING PAPER SERIES

\title{
DOMESTIC CAPITAL MARKET REFORM \\ AND ACCESS TO GLOBAL FINANCE: MAKING MARKETS WORK
}

\author{
Peter Blair Henry \\ Peter Lombard Lorentzen \\ Working Paper 10064 \\ http://www.nber.org/papers/w10064
NATIONAL BUREAU OF ECONOMIC RESEARCH
1050 Massachusetts Avenue
Cambridge, MA 02138
October 2003

\begin{abstract}
Henry is Associate Professor of Economics at the Stanford University Graduate School of Business and a faculty research fellow of the National Bureau of Economic Research. Lorentzen is a doctoral student in Economics at the Stanford University Graduate School of Business and a researcher at the Center on Democracy, Development, and Rule of Law at Stanford University's Institute for International Studies. This article will appear in the book The Future of Domestic Capital Markets in Developing Countries, Brookings Institution Press 2003. Henry gratefully acknowledges the financial support of a National Science Foundation CAREER award, the Stanford Institute of Economic Policy Research (SIEPR), and the Center for Research on Economic Development and Policy Reform (CREDPR). The views expressed herein are those of the authors and not necessarily those of the National Bureau of Economic Research.
\end{abstract}

(C2003 by Peter Blair Henry and Peter Lombard Lorentzen. All rights reserved. Short sections of text, not to exceed two paragraphs, may be quoted without explicit permission provided that full credit, including (C) notice, is given to the source. 
Domestic Capital Market Reform and Access to Global Finance: Making Markets Work Peter Blair Henry and Peter Lombard Lorentzen

NBER Working Paper No. 10064

October 2003

JEL No. F3, O1, G3

\author{
ABSTRACT \\ Contrary to the predictions of standard economic theory, capital market liberalization has been a \\ mixed blessing for many countries. Liberalization of debt inflows exposes economies to the risk of \\ crises stemming from sudden changes in investor sentiment. Equity market liberalizations, on the \\ other hand, have promoted growth in almost every liberalizing country. Yet equity market \\ liberalizations have not had as strong an effect as might be expected. To convince outsiders to \\ invest, countries must put in place laws and supporting institutions to protect the rights of minority \\ shareholders. Countries with such protections tend to have larger, more efficient, and more stable \\ stock markets than those that do not. \\ Peter Blair Henry \\ Stanford University \\ Graduate School of Business \\ Littlefield 277 \\ Stanford, CA 94305-5015 \\ and NBER \\ pbhenry@stanford.edu \\ Peter Lombard Lorentzen \\ Stanford University \\ lorentzen@stanford.edu
}


Over a decade ago, Robert Lucas asked the following question: Why doesn't more capital flow from rich to poor countries? His point was simple. Poor countries have lower capital-to-labor ratios than rich ones. Under standard neoclassical assumptions, the rate of return to capital in poor countries should be higher than in the developed world, attracting capital until risk-adjusted rates of return are equalized. In other words, market pressures should lead to a positive net transfer of resources to less-developed countries, thus boosting their growth rates. Lucas encouraged us to think about the obstacles that prevent such flows from occurring.

When Lucas asked his question, the prevailing wisdom was that capital flows to developing countries were a good idea. More than ten years later, intellectual opinion has shifted. A heated debate over capital account liberalization has followed in the wake of financial crises in Asia, Russia, and Latin America. Opponents of the process now argue that capital account liberalization invites speculative hot money flows, increases the likelihood of financial crises, and brings no discernible economic benefits. Some economists have gone so far as to assert that open capital markets may be detrimental to economic development. $^{1}$

With the debate over the wisdom of free capital flows still raging, it is at least a little presumptuous to write a paper that explains how developing countries can increase their integration with world capital markets without first addressing the underlying assumption that such integration is beneficial.

The paper is organized as follows. The first section examines capital market liberalization, establishing that there are indeed substantial benefits to increased capital market integration. The increasingly popular, negative view of capital account liberalization comes about partly from a failure to distinguish between equity market liberalization and debt market liberalization. After equity market liberalization, capital becomes cheaper, investment booms, and economic growth increases. In contrast, liberalization of debt markets has often led to great difficulty, as banks, companies, and governments

1. Bhagwati (1998); Rodrik (1998); Stiglitz (2002). 
often become vulnerable to changes in financial market perceptions of their ability to pay back loans.

The evidence outlined can be distilled into two key lessons. First, the liberalization of dollardenominated debt flows should proceed slowly and cautiously: Countries should refrain from premature liberalization of dollar-denominated foreign borrowing. The second lesson is that countries have thus far derived substantial economic benefits from opening their stock markets to foreign investors; there is no reason to think that future liberalizers will be any different in this respect.

The second section turns to liberalization of the stock market. Although the effects of equity market liberalization are positive and substantial, they fall far short of the torrent of capital flow to the developing world implied by the theory of perfect markets. New theories in economics and finance developed over the past three decades have highlighted the inefficiencies that can result when not all parties to a transaction are equally well informed. Such asymmetric information problems can make investors reluctant to put their money in companies for two reasons. First, they may worry about the adverse selection or "lemons" problem, wherein only the worst companies offer their shares. Second, moral hazard or agency problems raise the concern that even money invested in a good company may be misspent on managerial perks or even stolen outright through accounting tricks.

Over the past few years, cross-country econometric research on corporate governance, law, and finance has provided empirical support for the importance of such information problems. In addition, some of this research hints at the relative effectiveness of different reform strategies for increasing foreign participation in developing-country equity markets. However, given the relatively small number of countries with stock markets and the large number of plausible alternative explanations for large, prosperous equity markets, the statistical robustness of these conclusions cannot be taken for granted. Thus the findings of this research should be treated as tentative. Nevertheless, stronger laws and regulatory institutions that protect investors (whether domestic or foreign) from colluding insiders are strongly correlated with deeper and more robust equity markets. The third section discusses this literature and its policy implications in detail. A fourth section concludes. 


\section{Capital Account Liberalizations and Access to Global Finance}

Capital account liberalization was once seen as an inevitable step along the path to economic development for poor countries. Liberalizing the capital account, it was said, would permit financial resources to flow from capital-abundant countries, where expected returns were low, to capital-scarce countries, where expected returns were high. The flow of resources into the liberalizing countries would reduce their cost of capital, increase investment, and raise output. ${ }^{2}$ The principal policy question was not whether to liberalize the capital account, but when — before or after undertaking macroeconomic reforms such as stabilization of inflation and liberalization of trade. ${ }^{3}$ Or so the story went.

In recent years intellectual opinion has moved against capital account liberalization. Financial crises in Asia, Russia, and Latin America have shifted the focus of the conversation from when countries should liberalize to whether they should do so at all. Opponents of the process argue that capital account liberalization invites speculative hot money flows, increases the likelihood of financial crises, and brings no discernible economic benefits. Some economists have gone so far as to suggest that open capital markets may even be detrimental to economic development. ${ }^{4}$ Must developing countries maintain financial self-sufficiency even as they reap the benefits of openness to trade? In reality, the choice is not so stark.

Recent research demonstrates that the answer to the question "Is capital account liberalization helpful or harmful?" depends critically on the type of liberalization undertaken. While liberalization of debt flows has gotten many countries in trouble, liberalization of portfolio equity flows has been associated with booming stock markets, greater capital investment, and faster economic growth.

In its broadest form, capital account liberalization can be any decision by a country's government that allows capital to flow more freely in or out of that country. Allowing domestic businesses to obtain loans from foreign commercial banks, allowing foreigners to purchase domestic debt instruments (both

2. See Fischer (1998); Summers (2000).

3. See McKinnon (1991).

4. See Bhagwati (1998); Rodrik (1998); Stiglitz (2002). 
corporate and sovereign), and allowing foreigners to invest in the domestic stock market are three examples. At a minimum, we need to distinguish between two categories of liberalization: those that involve debt and those that involve equity. Although this is an oversimplification, it is useful for driving home the following point. Debt financing and equity financing are different. This point may seem obvious, but it has gotten lost in the heated debate over whether developing countries should have open capital markets.

A debt contract has very different characteristics from an equity contract. A debt contract requires regular payments regardless of the borrower's economic circumstances, while an equity contract involves risk-sharing — large payouts for shareholders when times are good and little to nothing when times are bad. In other words, unlike debt servicing obligations, which are constant, variations in profits and dividends are procyclical and tend to stabilize the balance of payments.

Liberalization of foreign borrowing restrictions typically leads to an over-reliance on debt financing for the liberalizing countries. In the 1970s countries became over-leveraged as governments obtained large quantities of floating-rate commercial bank loans. The 1980s debt crisis then demonstrated that the fixed-payment schedules of debt contracts can induce large inefficiencies when economic conditions turn out to be worse than anticipated at the time the debt contract was signed. ${ }^{5}$

Nor, as emphasized by John Williamson, "is it just the flow of payments to service the debt that theory suggests is more likely to vary in a stabilizing way for equity than for debt. The debt crisis was caused not just by high and variable interest rates magnifying the service payments due, and by the reduction in export earnings with which to service the debt, but most immediately and powerfully by the cutoff in new lending without any similar curb on the requirement to pay amortization."

At first glance, it may seem that foreign purchase of equities on the domestic stock market could also be reversed if and when foreign investors become concerned about a country's prospects. But foreigners cannot simply demand their money back. They have to sell their shares. Prices will drop as

5. See Fischer (1987). 
soon as other market participants (domestic or foreign) anticipate the sudden increase in supply.

Furthermore, as prices fall, expected returns rise so that the incentive to sell equity is no longer as strong. Loans, in contrast, have to be serviced even after adverse information becomes known, so that creditors rush to get their money while they can. In other words, the risk-sharing characteristics of an equity contract provide a kind of built-in stabilization mechanism, which suggests that foreign sales of portfolio equity are not likely to pose a particular threat to the domestic economy. ${ }^{7}$

In the 1990s countries turned to bonds instead of bank loans as their principal source of finance, but the outcome was largely the same. A number of economists have documented that excessive shortterm borrowing in dollars by banks, companies, and governments played a central role in the Asian financial crisis. ${ }^{8}$ In essence, the mismatch between the term structure of borrowers' assets, which were typically long term and denominated in local currency, and their liabilities, which were short term and denominated in dollars, placed these countries in an extremely vulnerable position. Any bad news that made their lenders reluctant to extend new loans created an immediate liquidity problem. A bunching of long-term debt maturity profiles creates a similar vulnerability. Beyond the Asian crisis, it appears that excessive short-term borrowing in dollars played a central role in precipitating almost every emergingmarket financial crisis during the 1990s. ${ }^{9}$

Thus a key lesson is that once external debt flows have been liberalized, it is of utmost importance that the magnitude and maturity profile of the country's external debt liabilities be compatible with the magnitude and maturity profile of its assets. That the liberalization of external debt financing can quickly generate liquidity problems for a country is a well-known phenomenon that dates back at least as far as Chile in the late 1970 s. $^{10}$

The empirical distinction between debt and equity flows is as important as the theoretical

$\overline{\text { 6. Williamson (1997, p. 288). }}$

7. Choe, Kho, and Stulz (1999).

8. See Furman and Stiglitz (1998); Radelet and Sachs (1998).

9. See Dornbusch (2000); Feldstein (2002). 
distinctions, because the composition of capital flows to developing countries has shifted drastically over the past twenty-five years. Table 7-1 breaks the composition of capital flows to developing countries into five major categories: public and publicly guaranteed debt flows, private nonguaranteed debt flows, foreign direct investment (FDI), portfolio equity, and grants. The sum of the first two categories reflects all debt flows to less-developed countries. There are three salient points to be made about table 7-1.

First, the lion's share of capital flows to developing countries from 1970 to 1984 took the form of debt. The five-year averages from 1970 to 1984 show that debt typically accounted for about 80 percent of all capital flows. Second, there were no portfolio equity flows to these countries from 1970 to 1984 . The fact that portfolio equity flows were nonexistent is a direct consequence of the fact that these countries did not allow foreigners to own shares in their domestic stock markets (a point we revisit shortly). Third, a dramatic shift in the composition of these flows took place starting in the five-year period from 1985 to 1989 . Portfolio equity flows as a fraction of total capital flows rose from less than 0.1 percent in 1980-84 to 18.7 percent in 1990-95, an increase of almost two hundred fold. Debt flows as a fraction of total capital flows fell from 82 percent in 1980-84 to 50 percent in 1990-95. FDI flows as a fraction of total capital flows increased from 13 percent in 1980-84 to 28 percent in 1990-95.

One of the principal reasons why countries became so reliant on debt during the 1970s was rather straightforward — foreign shareholding was banned. Countries could not rely on portfolio equity to finance development because their governments did not allow foreign investors to purchase shares in the domestic capital market. The import-substitution development strategy in vogue at the time discouraged integration with the global economy in general, and the writings of academic dependency theorists reinforced concerns about the negative political and economic consequences of widespread foreign ownership in particular. ${ }^{11}$

In the late 1980s and early 1990s, perhaps in part as a response to the debt crisis, countries all over the developing world decided to open their stock markets to foreign investment. Liberalizing the

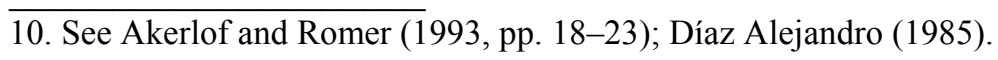


stock market - opening it to foreign investors - is one of the most important domestic capital reforms that developing countries can undertake and a necessary (but not sufficient) condition for increasing their access to global finance.

\section{Stock Market Liberalization}

Although numerous studies have shown that premature liberalization of dollar-denominated debt flows in the capital account has deleterious effects, there has been a relative dearth of evidence on the effects of equity market liberalizations. Recent work has begun to address this deficiency, and a consensus is forming that equity market liberalization reduces developing countries' cost of capital. ${ }^{12}$

Identifying the date of stock market liberalization is the first step in determining whether stock market liberalization has any discernible economic effect. Since markets are forward-looking, the most important question is, when does the market first learn of a credible, impending liberalization? In principle, identifying a liberalization date involves simply finding the date on which the government declares that foreigners may purchase domestic shares. In practice, the liberalization process is not so transparent. In many cases, there is no obvious government declaration or policy decree.

When there is no salient liberalization decree, liberalization is taken here to be the date on which a closed-end country fund was established. Closed-end funds are often the impetus for a spate of subsequent market openings, which further increase integration. ${ }^{13}$ Table 7-2 presents a list of the eighteen countries in the sample, the date of their first stock market liberalization, and the means by which they liberalized. For example, the table shows that the modal means of liberalization occurred through the establishment of a closed-end country fund. ${ }^{14}$

11. See Cardoso and Faletto (1979); Evans (1979).

12. See Bekaert and Harvey (2000); Henry (2000a, 2000b, 2003); Martell and Stulz (2003); Stulz (1999); Tesar and Werner (1998).

13. Bekaert and Harvey (2000); Henry (2000a).

14. While there is broad agreement that liberalization reduces the cost of capital, there is some disagreement about the exact timing of liberalizations. This matters, in principle, because the estimated size of the reduction in the cost 
The establishment of a country fund in particular — and stock market liberalizations in general— may seem like a narrow way to define capital account liberalization, but it is precisely the narrowness of stock market liberalizations that make them more useful for two specific reasons. First, focusing on stock markets alone helps us to distinguish the consequences of equity market liberalization from those of debt market liberalization. Second, studies that use broad indicators of liberalization focus on cross-sectional data, examining the long-run correlation between average openness and average investment. ${ }^{15}$ Examining the correlation between average openness and investment tells us whether investment rates are permanently higher in countries with capital accounts that are more open. The problem with this approach is that economic theory makes no such prediction.

What the theory does predict is that capital-poor countries will experience a temporary increase in investment when they liberalize. Hence, the relevant issue is not whether countries with open capital accounts have higher investment rates, but whether investment rates increase in the immediate aftermath of liberalization. The most transparent way of testing this prediction is to compare investment rates during episodes of liberalization with investment rates during periods of no liberalization. Because they constitute a radical shift in the degree of capital account openness, stock market liberalizations provide ideal natural experiments for confronting the theory with data.

\section{Stock Market Liberalizations: The Cost of Capital, Investment, and Growth}

The data indicate that, on average, opening up to foreign shareholders leads to a 38 percent increase in the real dollar value of the stock markets in liberalizing countries. ${ }^{16}$ Stock market liberalization does not alter the functioning of these companies in any way; liberalization only changes

of capital depends on the liberalization date one chooses. However, changing liberalization dates has virtually no effect on the basic conclusion. All of the evidence we have indicates that liberalization reduces the cost of capital and suggests that the effects are economically significant, even if we cannot precisely pin down the magnitudes. 15. See for example, Rodrik (1998).

16. Henry (2000a). This number varies according to the liberalization date. Martell and Stulz (2003) report even larger effects. 
the ownership of the shares of the companies listed on a country's stock exchange. Then, is the increase in share prices evidence that liberalization drives domestic stock prices away from the fundamentals and leads to stock market bubbles? Not necessarily.

The price of a stock depends on the expected future dividends to be paid by that stock and the discount rate shareholders apply to those expected future dividends. The discount rate has two components: the interest rate and the equity premium. Liberalization reduces interest rates through the inflow of foreign funds from countries with more plentiful capital. Stock market liberalization also reduces the equity premium, because emerging-market stocks provide diversification benefits for investors in countries like the United States. ${ }^{17}$ In other words, stock market liberalization leads to a lower cost of equity capital. Thus there are sound fundamental reasons for share prices to rise when the stock market is liberalized, and we seem to observe this in reality.

Exactly who benefits from the increase in share prices and the decline in the cost of capital? Clearly, domestic shareholders benefit: Those who sell their shares realize capital gains, and those who continue to hold their shares see the value of their portfolios increase. Some foreign shareholders may reap immediate capital gains if they get in early on the country's "initial public offering," but the more important benefit is the long-term reduction in risk they get from diversifying their portfolios.

Domestic residents who do not own shares also benefit from liberalization, although for less obvious reasons. When a stock market increases in value, this is equivalent to a fall in the cost of capital through that market. For a given capital-raising requirement, a higher stock price means that fewer shares need to be issued. Figure 7-1 illustrates the fall in the cost of capital that occurs when developing countries liberalize the stock market. The figure plots the average aggregate dividend yield across the liberalizing countries in event time (year 0 is the year of liberalization). The average dividend yield falls roughly 240 basis points - from an average level of 5.0 percent in the five years prior to liberalization to

17. Chari and Henry (forthcoming). 
an average of 2.6 percent in the five years following liberalization. ${ }^{18}$

Although the immediate effect of liberalization is to raise share prices and lower the cost of capital, this is not the end of the story. The lower cost of capital encourages firms to build new factories and install new machines because some investment projects that were not profitable before the stock market liberalization are profitable after liberalization.

The increased investment that should result from stock market liberalization is particularly important for emerging economies, because more investment should lead to faster economic growth and higher wages for workers. ${ }^{19}$ Thus stock market liberalization should generate substantial economic benefits, even for those individuals who did not own shares before the liberalization and therefore do not reap the capital gains associated with the increase in share prices.

It sounds plausible that a lower cost of capital should lead to increased investment, but what is the reality? Figure 7-2 demonstrates that, on average, countries experience an increase in investment when they liberalize the stock market. The growth rate of the capital stock rises 1.1 percentage points in the aftermath of liberalization - from an average of 5.4 percent a year in the period before to an average of 6.5 percent in the period after liberalization.

While liberalization leads to a sharp increase in investment on average, it is also important to know whether this is a uniform effect: Do all countries experience higher investment, or do just a select few drive the results? In order to address this question, recent research looks at the results on a country-

18. Recall that the dividend yield, $D / P$, is given by the following formula: $D / P=r-g$, where $D$ is the dividend, $P$ is the price, and $g$ is the expected growth rate of $D$. It is legitimate to interpret a fall in the dividend yield as a decline in the cost of capital, if there is no change in the expected future growth rate of dividends at the time of liberalization. But, as we discuss shortly, stock market liberalizations usually are accompanied by other economic reforms that may increase the expected future growth rate of output and dividends. Economic reforms do have significant effects on the stock market, but the financial effects of liberalization remain statistically and economically significant, after controlling for contemporaneous reforms (Henry 2000a, 2002).

19. The increase in the growth rate of output will only be temporary. Because of diminishing returns to capital, it is impossible for a country to achieve permanently higher growth rates by simply increasing the capital stock. The gains in the level of GDP per capita, however, will be permanent. 
by-country basis. In one study, only two of the countries in the sample did not experience abnormally high rates of investment in the first year after liberalization. In the second year after liberalization, only one of the countries did not experience abnormally high rates of investment. ${ }^{20}$

Theory also tells us that increased investment should raise productivity and economic growth. Figure 7-3 shows that, as predicted, the growth rate of output per worker rises in the aftermath of liberalization - from an average of 1.4 percent a year in the period before to an average of 3.7 percent a year in the period after liberalization.

\section{Stock Market Liberalization and Other Economic Reforms}

Stock market liberalizations are usually accompanied by other economic reforms. Therefore, it is important to ask whether these economic reforms would have caused large increases in stock prices, investment, and growth, even if there had not been any stock market liberalization. While the financial and economic effects of stock market liberalization remain statistically and economically significant after controlling for contemporaneous reforms, the other economic reforms are also important sources of growth.

To see the point, consider in greater detail the result illustrated by figure 7-3: per capita gross domestic product (GDP) growth increases following liberalization. On the one hand, there is nothing surprising about figure 7-3. Whereas figures 7-1 and 7-2 document behavioral responses of prices and quantities of capital to liberalization, figure 7-3 simply provides a mechanical check of the standard growth-accounting equation:

$$
\hat{Y}=\hat{A}+\alpha \hat{K}+(1-\alpha) \hat{L}
$$

where a circumflex over a variable denotes the change in the natural log of that variable. ${ }^{21}$

\section{Henry (2000b).}

21. In words, this equation says that the growth rate of output equals the growth rate of total factor productivity plus capital's share in output $(\alpha)$ times the growth rate of the capital stock plus labor's share in output $(1-\alpha)$ times the 
The interesting point about figure 7-3 is that the increase in the growth rate of output per worker is too large to be explained by the increase in investment. A few simple calculations illustrate the point. The elasticity of output with respect to capital, $\alpha$, is typically around 0.33 . So, based on figure 7-2, we would expect the growth rate of output per worker after liberalization to be about 0.363 (0.33 times 1.1) percentage points higher. But figure 7-3 displays a 2.3 percentage point increase in the growth rate of output per worker. All else equal, a 1.1 percentage point increase in the growth rate of the capital stock can produce a 2.3 percentage point increase in the growth rate of output per worker only if the elasticity of output with respect to capital is on the order of 2 !

The increase in growth due to liberalization is slightly larger than 1 percentage point after controlling for a number of variables. ${ }^{22}$ Nevertheless, this finding still requires an elasticity of output with respect to capital that is greater than 1 . What explains the inconsistency of this finding with standard production theory? The answer, of course, is total factor productivity (TFP) growth. Equation 7-1 shows that any increase in the rate of growth of output that is not accounted for by an increase in the growth rate of capital and labor must be the result of an increase in $\hat{A}$, the growth rate of TFP. While we typically interpret $\hat{A}$ as the growth rate of the stock of productive ideas or technology, any economic reform that raises the efficiency of a given stock of capital and labor also increases $\hat{A}$, even in the absence of technological change.

Economic institutions and social infrastructure can also be crucial in determining the level of human capital accumulation and in turn setting the marginal product of capital. ${ }^{23}$ In other words, the rate of return to capital may be low because emerging economies fail to create an environment where (1) entrepreneurs are free to pursue new productive opportunities and (2) lenders have an incentive to extend capital to the private sector.

growth rate of the labor force. Starting with the standard production function, $Y=A K^{\alpha} L^{1-\alpha}$, taking natural $\operatorname{logs}$ on both sides and differentiating with respect to time, yields this equation.

22. Bekaert, Harvey, and Lundblad (2001).

23. Kremer (1993). 
Consider the gap between G-7 countries and emerging economies using some common measures of institutional development. According to one measure of social infrastructure, ${ }^{24}$ the median G-7 country ranks fourteenth of 130 countries, while the median emerging economy ranks sixty-fourth. ${ }^{25}$ A look at the Heritage House 2003 Index of Economic Freedom yields similar results. Out of 161 countries, the median G-7 country ranks nineteenth, and the median emerging economy ranks seventy-second. ${ }^{26}$

Stock market liberalization commonly takes place concurrently with a number of other institutional and macroeconomic reforms. Because of this, it is important to think carefully about how to interpret the data. Consider a few simple pictures. Standard trade theory predicts that trade liberalization will increase TFP. As countries tilt production toward their comparative advantage, they experience an increase in output for a given stock of capital and labor. Figure 7-4 plots the average growth rate of output per worker across all of the countries in the sample following trade liberalization. ${ }^{27}$ The figure shows that the average growth rate of output per worker rises 1.5 percentage points following trade liberalizationfrom an average of 0.6 percent a year in the five years preceding trade liberalization to an average of 2.1 percent a year in the five years after.

Stabilizing inflation may also increase TFP, because high inflation generates incentives for workers and producers to divert resources away from productive activities and toward activities that help them to avoid the costs of high inflation. Economic research has found that stabilizing high inflation is good for asset prices, investment, and output. ${ }^{28}$ Figure 7-5 plots the average growth rate of output per worker across all of the countries in the sample following inflation stabilization programs. ${ }^{29}$ Figure $7-5$

24. Hall and Jones (1999).

25. We use the emerging economies listed in table 7-3. These countries, all of which have stock markets, are among the more successful of the less-developed countries. A more complete list of less-developed countries would only make the distinction sharper.

26. These data are available online at www.heritage.org/research/features/index/ [June 6, 2003].

27. The trade liberalization dates are taken from Sachs and Warner (1995).

28. Calvo and Végh (1998); Easterly (1996); Fischer, Sahay, and Végh (2002); Henry (2000b, 2002).

29. The inflation stabilization dates are taken from Henry (2002). In countries with multiple stabilization dates, the last date was chosen. 
shows that the growth rate of output per worker rises 0.8 percentage points following stabilization programs - from an average of 0.8 percent a year in the five years preceding stabilization to an average of 1.6 percent a year in the five years following stabilization.

Pictures are not conclusive, of course. To reach more reliable conclusions, one must work carefully to disentangle the effects of these and other reforms on growth. Our only point is that there are strong a priori theoretical reasons to expect reforms other than equity market liberalization to have a significant effect on economic growth. The raw data do no harm to this view and provide strong prima facie evidence that factors not related to capital markets play a significant role in explaining the increase in growth during the period after liberalization.

Hence, although this paper focuses primarily on the ways in which domestic capital market reforms can improve developing countries' access to capital, we would be remiss not to underscore the following point. Domestic reforms that improve the efficiency with which capital is utilized are at least as important as reforms increasing the quantity of capital that domestic markets are able to attract. In addition to macroeconomic reforms such as inflation stabilization and trade liberalization, reforms that improve the efficiency with which capital gets allocated can also raise TFP growth.

\section{Investor Protection and Access to Global Finance}

We have shown that whether liberalization succeeds or fails depends crucially on whether it is equity market liberalization or debt market liberalization. In general, liberalizing debt flows leads to crises, while liberalizing portfolio equity flows is associated with higher asset valuations, greater capital investment, and faster economic growth. The contrasting evidence on the effects of debt versus equity flows suggests that there may be a need for developing countries to shift their financing toward equity and away from debt.

But it is important to remember that international finance is a two-way street—borrowing requires lending. Therefore, policymakers must ask the following: Given the preferences of developedcountry suppliers of capital, what steps can be taken to shift the equilibrium financial mix toward equity 
and away from debt? Permitting foreign investors to hold stocks is a necessary step but is not sufficient by itself. We now explore the potential causes of an over-reliance on debt and suggest some steps that countries can undertake to remedy the situation.

Equity flows to developing countries have fallen far short of what one would expect given the scarcity of capital in these countries. Capital flows may be heavily tilted toward debt over equity because of institutions that intentionally or unintentionally skew the equilibrium mix. Even the initial boom in emerging stock markets led to much smaller increases in valuations (declines in the cost of capital) than one would expect to occur with the entry of foreign investors. ${ }^{30}$ Since the initial boom of the early $1990 \mathrm{~s}$, the flow of portfolio equity to emerging markets has slowed. ${ }^{31}$ While a recent study by the World Bank shows that developing countries' ratios of external debt to equity fell between 1997 and 2001, it is still not clear that they have fallen to prudent levels. ${ }^{32}$

Before one can prescribe a solution to the problem of weak equity flows, however, one must first identify the cause of the problem. At first glance, one is tempted to resort to home bias as an explanation. ${ }^{33}$ Does the fact that foreign investors hold far too few foreign securities account for developing countries' high ratios of debt to equity? No. Home bias can help to explain why overall levels of capital flows to developing countries are not what we would expect them to be. But home bias alone cannot explain why the composition of capital flows to developing countries is skewed toward debt over equity.

Put another way, taking the overall inflow of capital to developing countries as given, why do we see so little in the way of portfolio equity inflows relative to debt inflows? Two linked explanations suggest themselves. First, lack of transparency in equity markets makes investors reluctant to invest in emerging-market stocks; second, weak protection of the rights of equity investors reinforces the tendency

30. Martell and Stulz (2003); Stulz (1999).

31. Akyut, Kalsi, and Ratha (2003).

32. Suttle (2003, p. 9).

33. See Lewis (1999) for a survey of the home-bias literature. 
of capital suppliers to purchase debt rather than equity. We now discuss the economic theory behind these explanations before moving on to the accumulating empirical evidence supporting them.

\section{Asymmetric Information and Finance}

New theories in economics and finance developed over the past three decades have highlighted the inefficiencies that can result when not all parties to a transaction are equally well informed. Such asymmetric information problems can make investors reluctant to put their money in companies due to the problems of adverse selection, moral hazard, or both. If good companies are indistinguishable from bad companies, investors can only safely assume that all companies are bad. In that case, good companies will not receive a high enough price for their shares and will not list shares on the market, thus confirming investors' negative beliefs. Second, investors may be concerned about moral hazard or agency problems. Money invested in a good company may be misspent on unnecessary managerial perks or even stolen outright where accounting standards and enforcement bodies do not exist to restrain insiders. ${ }^{34}$ These insiders may be controlling shareholders, such as a founding family, a firm's top managers, or both.

A new literature on law and finance has found strong support for the importance of these legal and institutional factors in explaining why the magnitude of capital flows from rich to poor countries is smaller than we would otherwise expect. The degree to which a country's law protects the legal rights of minority shareholders exerts a significant influence on the size and robustness of capital markets. ${ }^{35}$ If investors get poor protection from a country, they will stay away. Table 7-3 shows that developing countries rank lower than developed countries on every major measure of investor protection: shareholder rights, creditor rights, efficiency of judicial system, rule of law, and rating of the accounting system. This underscores our point that allowing foreign investors into the country is a necessary but not sufficient condition for increased capital market integration.

34. Jensen (1986); Shleifer and Vishny (1997).

35. La Porta and others $(1997,1998,2002)$. 
For example, Shleifer and Wolfenzon show that weaker investor protection may reduce the marginal product of capital and can eliminate the incentive for capital to flow from rich to poor countries. According to their argument, the amount of capital that does flow to emerging economies is only a fraction of what we would see in a world where minority shareholders in these countries enjoyed the same legal protection as their U.S. counterparts. ${ }^{36}$ In other words, stock market liberalization is a necessary but not sufficient condition for increased access to global equity capital.

The drastically lower capital-to-labor ratios in emerging economies may not translate into higher rates of return if there are significant cross-country differences in investor protection. We can think about such a claim in terms of the standard production theory discussed earlier. While economists have traditionally interpreted the parameter $A$ in the production function as the stock of ideas, $A$ is really an index of the efficiency with which a given stock of $K$ and $L$ can be transformed into $Y .{ }^{37}$ Therefore, any economic reform that raises the efficiency of a given stock of capital and labor will also increase $A$, even in the absence of technological change. Holding the stock of ideas constant, government distortions may reduce $A$ and lead to lower rates of return to capital than we would otherwise expect.

Ineffective investor protection is an important example of such a distortion. Since outside investors (whether foreign or domestic) know less about the firm's prospects and the behavior of the managers running it than do insiders, they will demand higher returns or stay out entirely. By mitigating the effects of asymmetric information, strong investor protection may help countries to attract more international capital. More protection should keep mobile domestic capital from leaving or being kept out of the financial markets and saved as cash or in nonfinancial assets (such as land or jewelry). Finally, better disclosure will improve efficiency regardless of whether protections increase the total stock of capital, thus helping countries to make better use of the capital they already have.

Institutions to mitigate moral hazard improve the ability of investors to monitor how their money is being used and make it easier for investors to step in when insiders start to misuse their power. In

36. Shleifer and Wolfenzon (2002). 
contrast, if some shareholders have disproportionate influence over the firm's policies, or if minority shareholders face roadblocks to active participation in decisionmaking, outside investors will hesitate to risk their money at such a firm, thus raising its cost of capital.

Institutions to mitigate adverse selection require firms listing new securities to provide more information and make them legally liable for the quality of this information. Because minority shareholders are unlikely to take an interest in the governance of a single firm when it is easier simply to sell the shares, it has also been suggested that it would be beneficial to have a strong public regulator with the incentives and capabilities to act on their behalf.

An important point of contention has been over who needs this protection. American research on corporate governance initially concerned itself with the problem of managers of a widely held firm with few concentrated shareholders. Because no individual shareholder owned enough shares of one firm to make it worth the effort to monitor, the concern was that managers would not be accountable. Outside the United States, however, the widely held firm is a rarity. Instead, most firms have a single dominant shareholder or group of shareholders (often the founding family or a government shareholder) that keeps close track of the business and may include the chief executive officer and other top managers. ${ }^{38}$ For this reason, we refer to "insiders" in general, leaving open the possibility that they may be managers, large shareholders, or both in any given company.

\section{Firm-level Corporate Governance}

One growing body of research has explored the relationship of firm-level corporate governance practices to valuations or performance. While the results of this research point to the value of good governance for firms, it fails to rule out crucial alternative theories and does not indicate whether there is a useful role for governments to play.

In general, firms with better corporate governance practices have better performance and higher

37. Solow (2001). 
valuations, especially in countries where the overall legal system is weak. ${ }^{39}$ A study of almost 3,000 Asian corporations found that a mismatch of cash flow rights to voting rights, such as through violations of "one-share, one-vote," through cross-shareholdings, or through pyramid ownership structures, is associated with significantly lower firm valuation. ${ }^{40}$ When surveyed, international investors have reported that they would avoid companies and countries with poor corporate governance. ${ }^{41}$

However, the policy implications of this are not entirely straightforward. The most obvious interpretation of the research is that if firms would only improve their corporate governance, they would have cheaper access to capital. This fails to address the question of why these companies have not done so already. Were they simply unaware that minority shareholders would require a higher return in order to invest in companies with opaque or exclusionary corporate governance practices? Alternatively, we must consider the possibility that these policies were consciously chosen. In that case, we need to understand why firm insiders decided that allowing more outside observation of and influence on corporate decisions was not worth the cost.

One possible cost is that shareholder involvement keeps the firm from making the best strategic decisions. It has been argued that the extra bureaucracy involved with fulfilling corporate governance requirements slows down firm decisionmaking. In a similar vein, the pressure to make quarterly results and to justify corporate decisions to the public could keep executives from taking a longer-term strategy. Another cost is that of disclosure. More public disclosure makes it harder to keep profitable lines of business out of the view of competitors. These costs reduce the value of the firm to all shareholders and hence could be good reasons for the failure to adopt corporate governance "best practices."

A more cynical view is that firms would benefit from the cheaper capital they could receive if they improved their governance but that insiders benefit more from continuing to extract rents from the

38. La Porta, López-de-Silanes, and Shleifer (1999).

39. Klapper and Love (2002); Newell and Wilson (2002).

40. Claessens and others (1999).

41. McKinsey and Company (2002). 
current "captive" shareholders than they would from taking their honest share of a well-governed firm. Alternatively, there might be some sort of coordination problem. If all firms in a country have significant internal governance problems, the first firm to reform might risk looking worse than other firms. For instance, if most firms in a country are reporting profits, but only because they violate international accounting standards in some respect, the first firm to switch over and admit it is running a loss may not benefit. If all firms are compelled to switch together, then the better firms will stand out.

Thus this firm-level research has ambiguous policy implications. Regulating stronger corporate governance measures from every firm in an economy when these firms have already demonstrated through their own choices that they do not want better corporate governance only makes sense under some circumstances. Otherwise it might harm the firms more than help them. The results of firm-level research do not help to answer this question, because they are consistent with either hypothesis.

\section{Measuring Investor Protection}

In recent years a growing body of econometric research has demonstrated that economies with fewer protections for minority shareholders, with weaker legal systems, or with reputations for corruption have smaller and weaker financial systems and grow more slowly. Such institutional problems not only make it harder for firms to access international capital but also make it harder for firms to convince domestic investors to entrust the firms with their money, reducing growth even in a closed economy.

Both the desired outcome (capital market development) and the proposed influences on it (effective legal systems, transparency, and so forth) can be measured in a variety of ways. The influences are particularly difficult to assess rigorously. Following the example of earlier cross-country research on the correlates of overall economic growth, initial work primarily used general indexes of "law and order," "rule of law," or "corruption" created by private business risk advisory services, by think tanks, or by

investment banks. ${ }^{42}$

42. See, for example, Demirgüç-Kunt and Maksimovic (1998). 
Such indexes have three main problems. The first is that these measures are somewhat subjective, giving substantial weight to the personal assessments of analysts or surveyed businesspeople. This affects their comparability and obscures what they are actually measuring. The second is that they are not focused on financial markets in particular, which may be more or less law-abiding than other parts of the economy. Finally, and perhaps most important for the present discussion, results based on such studies provide only very general policy implications. A reputation for corruption and an ineffective legal system are bad for the entire economy, not just for the financial sector, and there is no universally accepted "cure" for these ills.

A new wave of economic research has attempted to remedy this deficiency by systematically measuring specific financial regulations and institutions and statistically testing their effects. In the first major effort in this direction, La Porta, López-de-Silanes, Shleifer, and Vishny examine the financial laws and regulations of forty-nine countries to determine what level of protection they afford to creditors and shareholders. ${ }^{43}$ This work focuses on aspects of company law that might (in theory) act to mitigate the moral hazard problem.

Shareholder rights are measured by seven indicators, each taking a value of 1 if a particular law works in favor of minority shareholders and a value of 0 otherwise. Six of these are summed into an "antidirector rights" score that ranges from 0 to 6 . The first antidirector right is proxy by mail. If small shareholders must personally attend annual meetings in order for their voices to be heard, they are unlikely to do so and thus are effectively disenfranchised. The second, "shares not blocked," refers to a requirement in some countries that shareholders temporarily deposit their shares with the company or an intermediary in order to participate in general shareholders' meetings. Such provisions make it more difficult for shareholders to participate in corporate governance and restrict their ability to react to the meeting's events by trading immediately. The third right indicates whether voting rules give small shareholders a good opportunity to get a board representative through proportional voting or other means.

43. La Porta and others (1998). 
Countries earn the fourth point of the antidirector score if minority shareholders have means to challenge the company's or the board's decisions in court. The fifth point comes from requiring a relatively low percentage of shares in order to call an extraordinary shareholders' meeting, and the sixth comes from granting preemptive rights to existing shareholders to buy new issues.

Another crucial shareholder right, "one-share, one-vote," is kept separate from the basic index of antidirector rights because it has a somewhat different nature. This right indicates whether cash flow rights match voting rights. Where these rights do not match, some shareholders have disproportionate control over the firm. If these shareholders act to ensure the firm's long-term profitability and dividend distributions, then any additional voting rights are without value. In practice, a premium usually is associated with multiple voting shares, which suggests that the extra control over the firm pays off through something other than share appreciation or dividends. ${ }^{44}$

Creditor rights are measured with a four-point scale. The first point is earned if restrictions are placed on firms going into reorganization, since reorganization shelters debtors from their obligations to creditors. The second is earned if no automatic stay is placed on secured assets in reorganization, meaning that creditors can reclaim their collateral even in reorganization. The third point comes if secured creditors receive priority over other creditors such as the government or employees. The fourth point is earned if in reorganization management is automatically fired or the firm is placed under the supervision of a court or creditor-appointed agent.

There are a number of trade-offs to be made in the choice of data. First, financial laws and regulations in any country are far more complicated than can be represented in a simple index of rights. It might well be that some unique characteristic of the laws of one country gives shareholders much stronger or weaker rights than this index indicates. Alternatively, actual practice may be quite different from the laws on the books, with much stricter or weaker enforcement because of cultural or political factors. However, sensitivity to these nuances has only been achieved by using subjective ratings from country

44. Dyck and Zingales (2002). 
experts, which has a high cost in terms of consistency and comparability across countries.

The other trade-off is that these two measures focus only on the protection of the rights of shareholders and creditors after they have purchased the shares or bonds or made the loans. Although these are crucial in mitigating the moral hazard problem, they do not address the adverse selection problem. Recently, La Porta, López-de-Silanes, and Shleifer have collected a new set of data on laws dealing with the issuing of new securities, one that addresses the means by which securities purchasers can have confidence in the quality of the financial assets they are purchasing. ${ }^{45} \mathrm{We}$ discuss this at more length, after first examining what researchers have uncovered over the past six years using the initial data set described above.

The central finding of this research is that, as suspected, countries that have put in place fewer of these protections have smaller and weaker capital markets. To evaluate the strength of stock markets, La Porta, López-de-Silanes, Shleifer, and Vishny use three outcome measures. ${ }^{46}$ First, they estimate the value of listed shares held by minority shareholders and compare that to GDP. They also look at the total number of listed firms and at the annual number of initial public offerings relative to population — seeing more firms on the market suggests that equity markets have been an attractive and feasible source of capital and seeing more initial public offerings confirms that they remain so. Controlling for rule of law (using a rating from the International Country Risk Guide), GDP growth, and gross national product (GNP), they find that antidirector rights have a statistically significant effect on all three outcome measures but that one-share, one-vote does not. ${ }^{47}$

These effects are sharply attenuated or disappear when another factor is taken into account: the origin of the country's company law. Countries that have a company law based on the English commonlaw model, whether because of colonial legacy or some other connection, have larger capital markets. Countries that follow continental European models based on a civil law tradition, such as the German or

45. La Porta, López-de-Silanes, and Shleifer (2002).

46. La Porta and others (1997).

47. La Porta and others (1997). 
French, have significantly smaller equity markets. Although this reinforces the view that law matters for security markets, these measures of investor rights do not capture the most crucial ways in which it does so. As expected, overall rule of law also has a significant effect on the number of listed firms and the number of initial public offerings and, to a lesser extent, on the ratio of market capitalization to GDP.

For credit markets, which are less public and thus harder to measure, La Porta, López-de-Silanes, Shleifer, and Vishny use the sum of all private sector bank debt and all outstanding corporate bonds, divided by GNP. ${ }^{48}$ Stronger creditor rights have the expected effect of increasing total debt, but this effect is not statistically significant and is swamped once legal origin is taken into account.

The overall statistical weakness of these results might lead one to discount the importance of the specific shareholder and creditor rights measured, but this would not be the correct conclusion. First, the sample includes only a cross section of forty-nine countries, meaning only the most dramatic effects could be expected to show up as statistically significant. Second, these indexes measure only a few aspects of a variety of complex legal codes and practices. Countries with weaker investor rights by the main measures used may have compensating measures such as mandatory dividends for listed firms or legal reserve requirements for borrower firms. ${ }^{49}$ Third, regardless of the control variables used or the outcome variable chosen, strengthening the rights of shareholders and creditors has a positive effect on the size of capital markets. The lesson for policymakers should not be that the research lays out the best recipe for bigger capital markets but rather that protection of minority rights, in one form or another, must be among the ingredients.

Examination of other characteristics of financial systems with different rules reinforces the importance of shareholder rights. Ownership of large public companies is significantly more concentrated in countries with weaker investor protections. ${ }^{50}$ This suggests that these firms missed opportunities to bring in more capital for investment through broad issuance of equity shares and that the investors in

\footnotetext{
48. La Porta and others (1997).

49. La Porta and others (1998).

50. La Porta and others (1998).
} 
these firms are less diversified than they could be.

In addition, firms in countries with stronger shareholder rights pay out more dividends than do firms in the same industries in countries with weaker shareholder rights. ${ }^{51}$ Perhaps more important, rapidly growing firms in a country with strong shareholder protections pay less in dividends than do slowly growing firms in the same country, but this is not true in countries without such protections. This implies that less-protected investors feel compelled to extract dividends from their investments in highgrowth firms every year because they are not certain that these cash flows will be used wisely or distributed to shareholders later. This apparent need to maintain credibility by paying dividends may restrict the ability of firms to raise capital for longer-term investments or to pursue the best opportunities available. Firms located in countries with weaker investor protections have lower market valuations relative to their book assets, again supporting the basic result that investors in these countries do not trust firms to use their assets effectively or to pay out profits in dividends. ${ }^{52}$

Other researchers have used this data set to test further implications of the theory. Countries with stronger minority shareholder rights have more efficient capital allocation overall. In particular, these countries see less over-investment in declining industries. ${ }^{53}$ In countries with weaker investor protections, insiders are compelled to hold a larger share of their firms (and thus not diversify) as an extra assurance to outside investors that they will run the firm to maximize profits. ${ }^{54}$

Dyck and Zingales analyze transactions in which a controlling stake is sold as a block. They infer that the premium paid in such transactions above the market price reflects the extra value of control rights, as opposed to the cash flow rights of shares sold one-by-one. Where those premiums are high, capital markets are less developed and ownership is more concentrated, suggesting that these premiums are a good measure of market inefficiency. They find that more shareholder rights and more effective law

51. La Porta and others (2000).

52. La Porta and others (2002).

53. Wurgler (2000).

54. Himmelberg, Hubbard, and Love (2002). 
enforcement are associated with lower control premiums. This again supports the idea that controlling shareholders are less able to extract "private benefits" from a company when shareholder rights are in place, which should make investors more confident in investing in such economies. They also find that low private benefits are associated with wide circulation of daily newspapers, high rates of tax compliance, and competitive product markets. ${ }^{55}$

Investor rights not only affect how well markets function in normal times but also play a role in crises. Countries with weak corporate governance were particularly hard hit in the Asian financial crisis of 1997-98. In fact, it has been argued that weak corporate governance played a greater role than did conventional macroeconomic variables such as government budget balance, current account deficits, or foreign debt. This may occur because insiders are more likely to start or increase the pace of expropriation of the assets of a company during a downturn, if investors are unprotected. Knowing this, investors will pull out rapidly when conditions become unfavorable, contributing to a downward spiral such as that observed in Asia. ${ }^{56}$

\section{Mitigating Adverse Selection through Public and Private Enforcement}

In their next wave of data collection, La Porta, López-de-Silanes, and Shleifer turn to securities law relating to initial public offerings. ${ }^{57}$ As mentioned, these laws can be viewed as attempts to deal with the adverse selection or "lemons" problem, making investors more confident that a firm issuing new equity has told the truth about its financial situation. In collecting these new data, the researchers address this question at three levels. First, they assess the theoretical arguments that securities laws are potentially harmful because they keep firms and investors from independently making whatever arrangements are best for them. Second, even if law is helpful, it might work through effective public enforcement or it might work through "private enforcement," making it easier for private parties to make informed

55. Dyck and Zingales (2002).

56. Johnson and others (2000).

57. La Porta, López-de-Silanes, and Shleifer (2002). 
decisions and to take action when deceived. Finally, the researchers go further into the details of specific laws to see which appear to be most effective and whether that varies with context.

This new study analyzes data on twenty-two aspects of securities law, across the same forty-nine countries with large stock markets that were in the earlier database. As in the 1998 study, La Porta, López-de-Silanes, and Shleifer consider the three outcome variables of market capitalization to GDP, number of listed firms per capita, and number of initial public offerings per capita. ${ }^{58}$ On their first question, whether law matters at all, they answer "a definite yes," echoing their earlier results.

Having dealt with the not-entirely-straw man of the efficiently lawless equity market, they go on to examine what does work in more detail. The obvious theoretical alternative to relying solely on the market is to rely solely on public enforcement, a strong independent government regulator that they call the supervisor. However, they find somewhat mixed evidence for the value of this. Contrary to expectations, it does not seem to matter whether the supervisor is insulated from political influence, nor does it matter if the supervisor's resources are thinly spread across multiple areas of responsibility (for example, both banking and market supervision). Furthermore, the ability of the supervisor to issue criminal sanctions against issuers, distributors, or accountants is not associated with larger financial markets. However, giving the supervisor power to make regulations, to command documents from firms, and to order market participants to take or refrain from taking specific actions (such as disclosing certain information to the public or paying compensation to investors) is associated with larger securities markets relative to GDP.

La Porta, López-de-Silanes, and Shleifer find stronger evidence for the efficacy of a third way, what they call "private enforcement." Laws can facilitate private enforcement first by ensuring that investors have the information they need and second by making it easier for them to take legal action when they believe they have been deceived. This first aspect is measured by tallying up disclosure requirements in the law. Legal systems are ranked higher on this scale for requiring that firms deliver a

58. La Porta, López-de-Silanes, and Shleifer (2002). 
prospectus to investors before listing, for requiring more detail on directors' compensation, for requiring more detail on the issuer's ownership structure (especially insider ownership), and for requiring disclosure of irregular contracts and related-party transactions. Stricter disclosure requirements are highly correlated with securities market development.

The second aspect of private enforcement is quantified by examining where the burden of proof is placed in civil suits, should the investors believe that material information was left out of the prospectus. In the least investor-friendly regimes, investors must prove that defendants were grossly negligent or deliberately fraudulent, while at the opposite extreme defendants may be required to prove that they conducted due diligence or may even have no defense if they excluded important information for any reason. These standards are rated separately for distributors, issuers, and accountants. An additional criterion, whether distributors are expected to conduct due diligence on the prospectus, is added together with these to construct a burden of proof index. This index is also highly correlated with strong equity markets.

In addition to measuring the direct effects of these different laws, La Porta, López-de-Silanes, and Shleifer find support for an important interaction effect. Public enforcement works well in countries with an efficient judicial system, but not in countries with a weak judicial system. In contrast, private enforcement works well in either environment. This suggests that developing countries with an imperfect judicial system might find more immediate success facilitating private enforcement, since this could succeed in bringing in more investment even without the broader systemic reforms that might be necessary to fix a dysfunctional judiciary.

Furthermore, unlike the antidirector rights index, these effects do not become insignificant when controlling for legal origin. In fact, the strong negative effect of French legal origin itself disappears in most of the measures. When these securities laws are included in a regression together with antidirector rights, antidirector rights become insignificant. This suggests that all of the earlier results that relied on the shareholder rights indexes may have been proxying for these securities laws. That is, "French legal origin" describes a package of laws and regulations that tend to go together, including weak shareholder 
rights. Saying a country has "weak shareholder rights" (by the measures of La Porta, López-de-Silanes, Shleifer, and Vishny) is thus nearly indistinguishable from saying a country has a continental European legal origin, especially given the inherently small samples of cross-country regressions. But these newer results suggest that legal origin itself is just a proxy for other aspects of the system, such as these securities laws.

\section{Conclusions}

What can developing countries take away from this research? First, they need not forgo the benefits of foreign investment in order to avoid being buffeted randomly by the winds of global investor sentiment. Equity market liberalization appears to be a safe and healthy alternative to debt dependency. Second, developing countries must recognize that opening up to foreign equity investment is necessary but not sufficient to ensure these inward flows. The lists of laws that La Porta, López-de-Silanes, and Shleifer amalgamate into their various indexes might have the appearance of a recipe for strong markets: Put in place these rules, and international capital will flow in. Such a conclusion would be hasty, for a number of reasons. What we can say, however, is that laws, regulations, and government institutions can play an important role in mitigating problems of moral hazard and asymmetric information for investors and that this will help capital markets to grow.

The main problem with drawing direct prescriptions from this research is that it is unclear what the crucial elements are from the whole package of institutional features. With only a cross section of forty-nine countries to compare, we cannot draw a clear statistical distinction between the effects of any of these institutional features. It appears that the positive effect of antidirector rights found with the earlier data might just be a proxy for other aspects of securities law. ${ }^{59}$ Thus putting the set of antidirector rights into law without making other changes might have no effect or could even have unexpected negative effects. We might be more confident if we had systematic before-and-after data on put-in-place new laws,

59. La Porta and others (2002). 
but such data have not yet been collected.

Nevertheless, both theory and empirics point in the same general direction. More protection for shareholders is strongly associated with the size, efficiency, and stability of equity markets. The most recent findings of La Porta, López-de-Silanes, and Shleifer also suggest that cheaper reforms might actually be more effective. Rather than setting up a powerful independent supervisor responsible for criminal prosecution of market actors, governments might do just as well by simply requiring more disclosure of firms and making them responsible in civil court for these disclosures. This does not require the creation of a new bureaucracy or the funding of its investigations.

Some scholars instead argue that improving creditor rights and regulation of the banking system should take priority. In this view, equity markets in developing countries are just a sideshow, because most financing occurs through banks. ${ }^{60}$ While it is true that equity markets as yet play a small role in most developing countries and that an efficient commercial banking system is very desirable, this does not diminish the value of effective equity market reforms.

Developing-country equity markets are small and often insignificant precisely because they are poorly regulated. If small savers cannot trust that they will get a fair return from equity investments, they will instead deposit their money with a bank or other financial intermediary. Both the theoretical and empirical literature suggest that different types of business will be better served with different kinds of financing. ${ }^{61}$ If only bank loans are available, some kinds of businesses may have difficulty getting started or growing. Furthermore, if well-run banks have access to cheaper equity financing, they should be able to expand their size and scope to serve more domestic clients.

As countries continue to open their equity markets to foreign investors and improve the protection of minority shareholders, there is good reason to believe that equity markets will continue to grow in importance relative to debt. In addition to providing additional capital to fund growth opportunities, less reliance on debt financing in the future might also lessen the frequency and severity of emerging-market

60. Berglof and von Thadden (1999); Mishkin (2000). 
financial crises.

$\overline{\text { 61. Carlin and Mayer (2003). }}$ 


\section{References}

Akerlof, George, and Paul M. Romer. 1993. "Looting: The Economic Underworld of Bankruptcy for Profit.” Brookings Papers on Economic Activity 2: 1-74.

Akyut, Dilek, Himmat Kalsi, and Dilip Ratha. 2003. "Sustaining and Promoting Equity-Related Finance for Developing Countries." Global Development Finance: Striving for Stability in Development Finance. Washington: World Bank.

Bekaert, Geert, and Campbell Harvey. 2000. "Foreign Speculators and Emerging Equity Markets." Journal of Finance 55 (2): 565-613.

Bekaert, Geert, Campbell Harvey, and Christian Lundblad. 2001. "Does Financial Liberalization Spur Growth?” NBER Working Paper 8245. Cambridge, Mass.: National Bureau of Economic Research.

Berglof, Eric, and Ludwig von Thadden. 1999. "The Changing Corporate Governance Paradigm: Implications for Transition and Developing Countries.” Paper presented at the Annual World Bank Conference on Development Economics, World Bank, Washington.

Bhagwati, Jagdish. 1998. “The Capital Myth.” Foreign Affairs 77 (3, May-June): 7-12.

Calvo, Guillermo, and Carlos Végh. 1998. "Inflation Stabilization and Balance of Payments Crises in Developing Countries.” In John Taylor and Michael Woodford, eds., Handbook of Macroeconomics. Amsterdam: North-Holland.

Carlin, Wendy, and Colin Mayer. 2003. "Finance, Investment, and Growth.” Journal of Financial Economics 69 (1):191-226.

Cardoso, Fernando E., and Enzo Faletto. 1979. Dependency and Development in Latin America. Berkeley: University of California Press.

Chari, Anusha, and Peter Blair Henry. 2002. "Capital Account Liberalization: Allocative Efficiency or Animal Spirits.” NBER Working Paper 8908. Cambridge, Mass.: National Bureau of Economic Research. 
—. Forthcoming. "Risk Sharing and Asset Prices: Evidence from a Natural Experiment." Journal of Finance.

Choe, Hyuk, Bong-Chan Kho, and René M. Stulz. 1999. "Do Foreign Investors Destabilize Stock Markets? The Korean Experience in 1997." Journal of Financial Economics 54 (2, October): 227-64.

Claessens, Stijn, Simeon Djankov, Joseph P. H. Fan, and Larry H. P. Lang. 1999. "Expropriation of Minority Shareholders: Evidence from East Asia.” Washington: World Bank, Financial Operations Vice Presidency, Financial Economics Unit, March.

Demirgüç-Kunt, Aslı, and Vojislav Maksimovic. 1998. "Law, Finance, and Firm Growth.” Journal of Finance 53 (6, December): 2107-36.

Díaz Alejandro, Carlos. 1985. “Goodbye Financial Repression, Hello Financial Crash.” Journal of Development Economics 19 (September-October): 1-24.

Dornbusch, Rudiger. 2000. Keys to Prosperity: Free Markets, Sound Policy, and a Bit of Luck. MIT Press.

Dyck, Alexander, and Luigi Zingales. 2002. "Private Benefits of Control: An International Comparison." NBER Working Paper 8711. Cambridge, Mass.: National Bureau of Economic Research.

Easterly, William. 1996. “When Is Stabilization Expansionary?” Economic Policy 22 (April): 67-107. Evans, Peter. 1979. Dependent Development: The Alliance of Multinational, State, and Local Capital in Brazil. Princeton University Press.

Feldstein, Martin. 2002. "Economic and Financial Crises in Emerging Market Economies: Overview of Prevention and Management.” NBER Working Paper 8837. Cambridge, Mass.: National Bureau of Economic Research.

Fischer, Stanley. 1987. "Sharing the Burden of the Debt Crisis." American Economic Review, Papers and Proceedings 77 (2, May): 165-70.

—. 1998. "Capital Account Liberalization and the Role of the IMF." Princeton Essays in International Finance 20: 1-10. 
Fischer, Stanley, Ratna Sahay, and Carlos Végh. 2002. "Modern Hyper and High Inflations.” Journal of Economic Literature 40 (3, September): 937-80.

Furman, Jason, and Joseph Stiglitz. 1998. "Economic Crises: Evidence and Insights from East Asia." Brookings Papers on Economic Activity 2, pp. 1-114.

Hall, Robert E., and Charles I. Jones. 1999. “Why Do Some Countries Produce So Much More Output per Worker Than Others?" Quarterly Journal of Economics 114 (1): 83-116.

Henry, Peter Blair. 2000a. “Do Stock Market Liberalizations Cause Investment Booms?” Journal of Financial Economics 58 (1-2): 301-34.

_. 2000b. "Stock Market Liberalization, Economic Reform, and Emerging Market Equity Prices." Journal of Finance 55 (2): 529-64.

—. 2002. “Is Disinflation Good for the Stock Market?” Journal of Finance 57 (4): 1617-48.

_. 2003. "Capital Account Liberalization: The Cost of Capital and Economic Growth." American Economic Review 93 (2, May): 91-96.

Himmelberg, Charles P., R. Glenn Hubbard, and Inessa Love. 2002. "Investor Protection, Ownership, and the Cost of Capital." Policy Research Working Paper 2834. Washington: World Bank.

Jensen, Michael C. 1986. "The Agency Costs of Free Cash Flow: Corporate Finance and Takeovers." American Economic Review 76 (2, May): 323-29.

Johnson, Simon, Peter Boone, Alasdair Breach, and Eric Friedman. 2000. "Corporate Governance in the Asian Financial Crisis.” Journal of Financial Economics 58 (1-2): 141-86.

Klapper, Leora, and Inessa Love. 2002. “Corporate Governance, Investor Protection, and Performance in Emerging Markets.” Policy Research Working Paper 2818. Washington: World Bank.

Kremer, Michael. 1993. “The O-Ring Theory of Economic Development.” Quarterly Journal of Economics 108 (3): 551-75.

La Porta, Rafael, Florencio López-de-Silanes, and Andrei Shleifer. 1999. "Corporate Ownership around the World." Journal of Finance 54 (2, April): 471-517.

—. 2002. "What Works in Securities Laws." Unpublished manuscript. Stanford Law School. 
La Porta, Rafael, Florencio López-de-Silanes, Andrei Shleifer, and Robert W. Vishny. 1997. "Legal Determinants of External Finance.” Journal of Finance 52 (3): 1131-50.

—. 1998. "Law and Finance.” Journal of Political Economy 106 (6): 1113-55.

—. 2000. "Investor Protection and Corporate Governance.” Journal of Financial Economics 57 (1, October): 3-26.

—. 2002. "Investor Protection and Corporate Valuation." Journal of Finance 57 (3, June): 1147-70.

Lewis, Karen K. 1999. “Trying to Explain Home Bias in Equities and Consumption.” Journal of Economic Literature 37 (2, June): 571-608.

López-de-Silanes, Florencio. 2002. “The Politics of Legal Reform.” Economia 2 (2, Spring): 91-152.

Lucas, Robert E. Jr. 1990. "Why Doesn't Capital Flow From Rich to Poor Countries?" American Economic Review (2, May), 92-96.

Martell, Rodolfo, and René M. Stulz. 2003. "Equity Market Liberalizations as Country IPOs.” American Economic Review 93 (2, May): 97-101.

McKinnon, Ronald I. 1991. The Order of Economic Liberalization. Johns Hopkins University Press. McKinsey and Company. 2002. "Global Investor Opinion Survey: Key Findings.” Available at www.mckinsey.com/practices/CorporateGovernance/Research/ [July 2, 2003].

Mishkin, Frederic S. 2000. "Financial Market Reform.” In Anne O. Krueger, ed., Economic Policy Reform: The Second Stage. University of Chicago Press.

Newell, Roberto, and Gregory Wilson. 2002. “A Premium for Good Governance.” McKinsey Quarterly 3.

Radelet, Steven, and Jeffrey Sachs. 1998. “The East Asian Financial Crisis: Diagnosis, Remedies, Prospects.” Brookings Papers on Economic Activity 1: 1-91.

Rodrik, Dani. 1998. "Who Needs Capital Account Convertibility?” Princeton Essays in International Finance 207: 55-65.

Sachs, Jeffrey, and Andrew Warner. 1995. "Economic Reform and the Process of Global Integration." Brookings Papers on Economic Activity 1: 1-95. 
Shleifer, Andrei, and Robert W. Vishny. 1997. “A Survey of Corporate Governance.” Journal of Finance 52 (2, June): $737-83$.

Shleifer, Andrei, and Daniel Wolfenzon. 2002. "Investor Protection and Equity Markets.” Journal of Financial Economics 66 (1, October): 3-27.

Solow, Robert M. 2001. “Applying Growth Theory across Countries.” World Bank Economic Review 15 (2): $283-88$.

Stiglitz, Joseph. 2002. Globalization and Its Discontents. W.W. Norton.

Stulz, René M. 1999. “Globalization of Equity Markets and the Cost of Capital.” NYSE Working Paper 99-02. New York Stock Exchange.

Summers, Lawrence H. 2000. "International Financial Crises: Causes, Prevention, and Cures.” American Economic Review 90 (2): 1-16.

Suttle, Philip. 2003. "Financial Flows to Developing Countries: Recent Trends and Near-Term Prospects." Global Development Finance: Striving for Stability in Development Finance. Washington: World Bank.

Tesar, Linda L., and Ingrid M. Werner. 1998. "The Internationalization of Securities Markets since the 1987 Crash.” In Robert E. Litan and Anthony M. Santomero, eds., Brookings Wharton Papers on Financial Services 1998. Brookings.

Williamson, John. 1997. "Prospects for Avoiding Crises with Liberalized Capital Flows.” Estudios de Economía 24 (2): 287-95.

Wurgler, Jeffrey. 2000. "Financial Markets and the Allocation of Capital.” Journal of Financial Economics 58 (1, October): 187-214. 
Table 7-1 Composition of Capital Inflows to Developing Countries, 1970-95

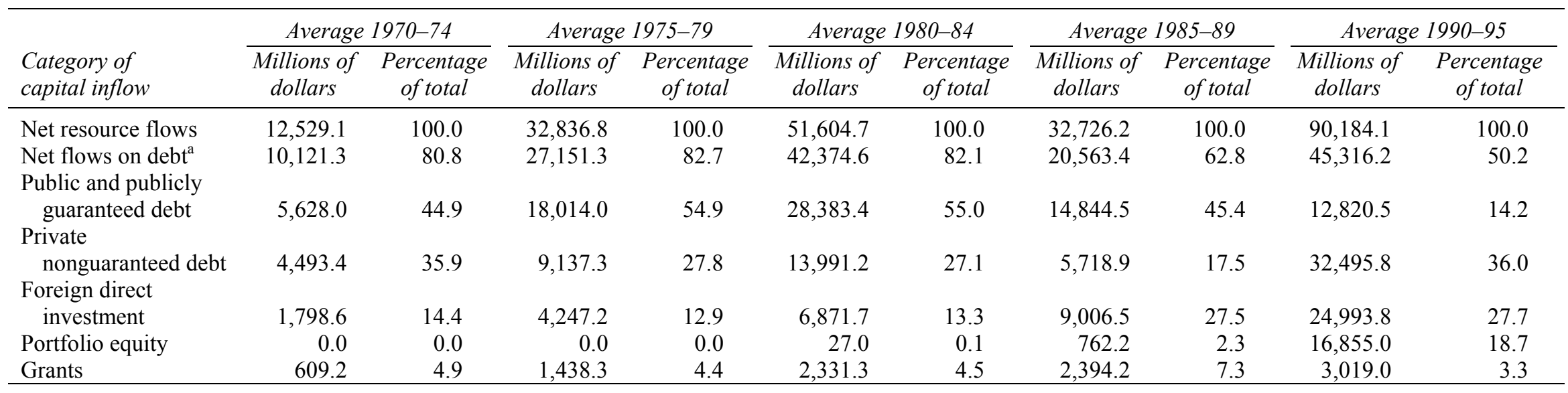

a. Public and publicly guaranteed debt plus private nonguaranteed debt. 
Table 7-2. Dates of Stock Market Liberalization, by Country

\begin{tabular}{lcc}
\hline Country & $\begin{array}{c}\text { Year of } \\
\text { liberalization }\end{array}$ & $\begin{array}{c}\text { Means of } \\
\text { liberalization }\end{array}$ \\
\hline Argentina & 1989 & Policy decree \\
Brazil & 1988 & Country fund \\
Chile & 1987 & Country fund \\
Colombia & 1991 & Policy decree \\
India & 1986 & Country fund \\
Indonesia & 1989 & Policy decree \\
Jordan & 1995 & Policy decree \\
Korea, Rep. of & 1987 & Country fund \\
Malaysia & 1987 & Country fund \\
Mexico & 1989 & Policy decree \\
Nigeria & 1995 & Policy decree \\
Pakistan & 1991 & Policy decree \\
Philippines & 1986 & Country fund \\
Taiwan & 1986 & Country fund \\
Thailand & 1987 & Country fund \\
Turkey & 1989 & Policy decree \\
Venezuela & 1990 & Policy decree \\
Zimbabwe & 1993 & Policy decree \\
\hline
\end{tabular}


Table 7-3. Investor Protection, by Country

\begin{tabular}{|c|c|c|c|c|c|}
\hline Country & $\begin{array}{c}\text { Rule } \\
\text { of law }\end{array}$ & $\begin{array}{l}\text { Judicial } \\
\text { efficiency }\end{array}$ & $\begin{array}{l}\text { Contract } \\
\text { repudiation }\end{array}$ & $\begin{array}{l}\text { Expropriation } \\
\text { risk }\end{array}$ & $\begin{array}{c}\text { Accounting } \\
\text { standards }\end{array}$ \\
\hline Argentina & 5.4 & 6.0 & 4.9 & 5.9 & 4.5 \\
\hline Brazil & 6.3 & 5.8 & 6.3 & 7.6 & 5.4 \\
\hline Chile & 7.0 & 7.3 & 6.8 & 7.5 & 5.2 \\
\hline Colombia & 2.1 & 7.3 & 7.0 & 7.0 & 5.0 \\
\hline Ecuador & 6.7 & 6.3 & 5.2 & 6.6 & NA \\
\hline Egypt & 4.2 & 6.5 & 6.1 & 6.3 & 2.4 \\
\hline Greece & 6.2 & 7.0 & 6.6 & 7.1 & 5.5 \\
\hline India & 4.2 & 8.0 & 6.1 & 7.8 & 5.7 \\
\hline Indonesia & 4.0 & 2.5 & 6.1 & 7.2 & NA \\
\hline Jordan & 4.4 & 8.7 & 4.9 & 6.1 & NA \\
\hline Kenya & 5.4 & 5.8 & 5.7 & 6.0 & NA \\
\hline Korea, Rep. of & 5.4 & 6.0 & 8.6 & 8.3 & 6.2 \\
\hline Malaysia & 6.8 & 9.0 & 7.4 & 8.0 & 7.6 \\
\hline Mexico & 5.4 & 6.0 & 6.6 & 7.3 & 6.0 \\
\hline Nigeria & 2.7 & 7.3 & 4.4 & 5.3 & 5.9 \\
\hline Pakistan & 3.0 & 5.0 & 4.9 & 5.6 & NA \\
\hline Peru & 2.5 & 6.8 & 4.7 & 5.5 & 3.8 \\
\hline Philippines & 2.7 & 4.8 & 4.8 & 5.2 & 6.5 \\
\hline South Africa & 4.4 & 6.0 & 7.3 & 6.9 & 7.0 \\
\hline Sri Lanka & 1.9 & 7.0 & 5.3 & 6.1 & NA \\
\hline Thailand & 6.3 & 3.3 & 7.6 & 7.4 & 6.4 \\
\hline Turkey & 5.2 & 4.0 & 6.0 & 7.0 & 5.1 \\
\hline Uruguay & 5.0 & 6.5 & 7.3 & 6.6 & 3.1 \\
\hline Venezuela & 6.4 & 6.5 & 6.3 & 6.9 & 4.0 \\
\hline Zimbabwe & 3.7 & 7.5 & 5.0 & 5.6 & NA \\
\hline \multicolumn{6}{|l|}{ Mean } \\
\hline Less-developed countries & 4.7 & 6.3 & 6.1 & 6.7 & 3.8 \\
\hline Developed countries & 9.1 & 9.1 & 9.2 & 9.5 & 6.4 \\
\hline
\end{tabular}

Source: López-de-Silanes (2002). 


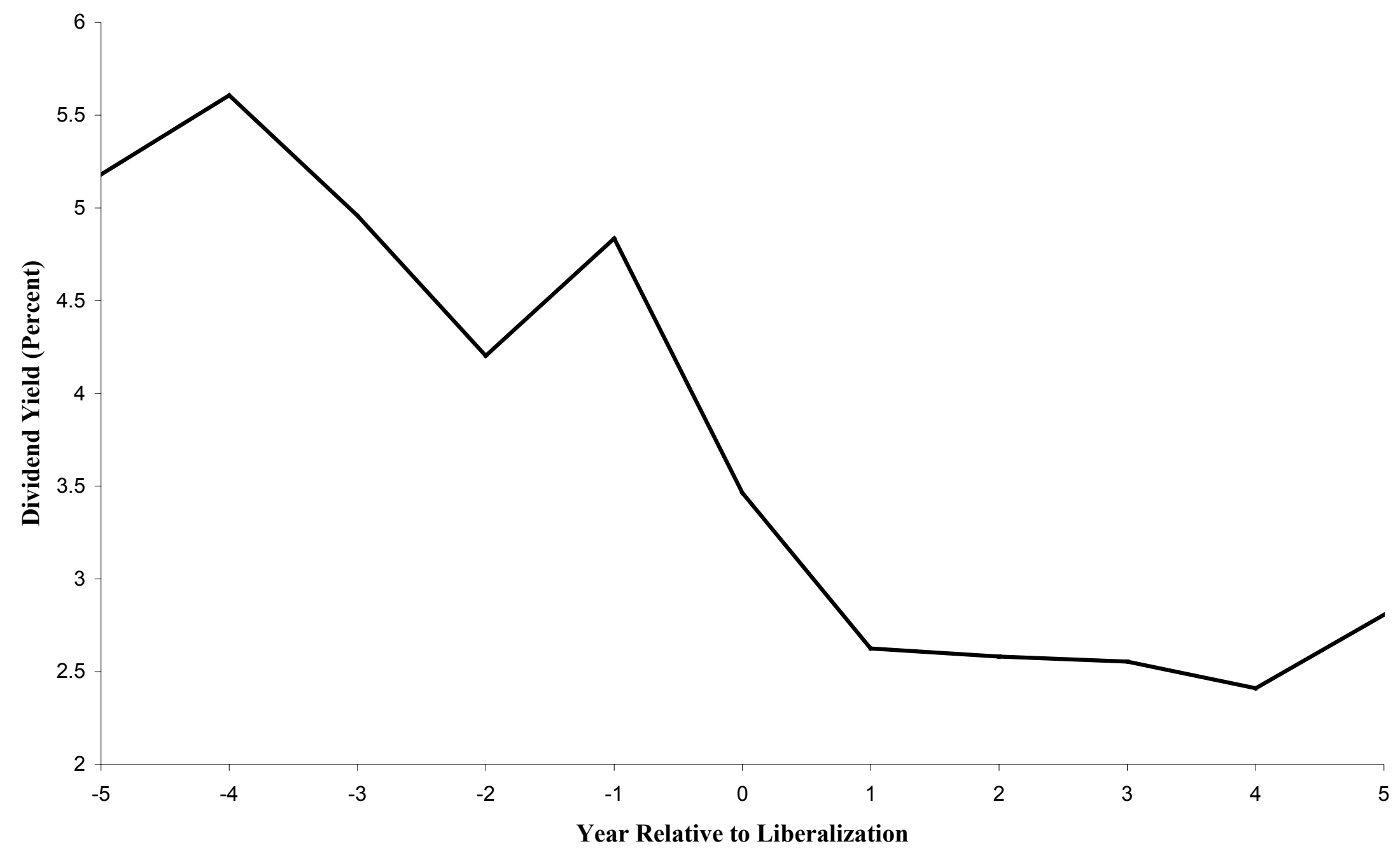

Figure 1. The Cost of Capital Capital Falls When Countries Liberalize the Capital Account. 


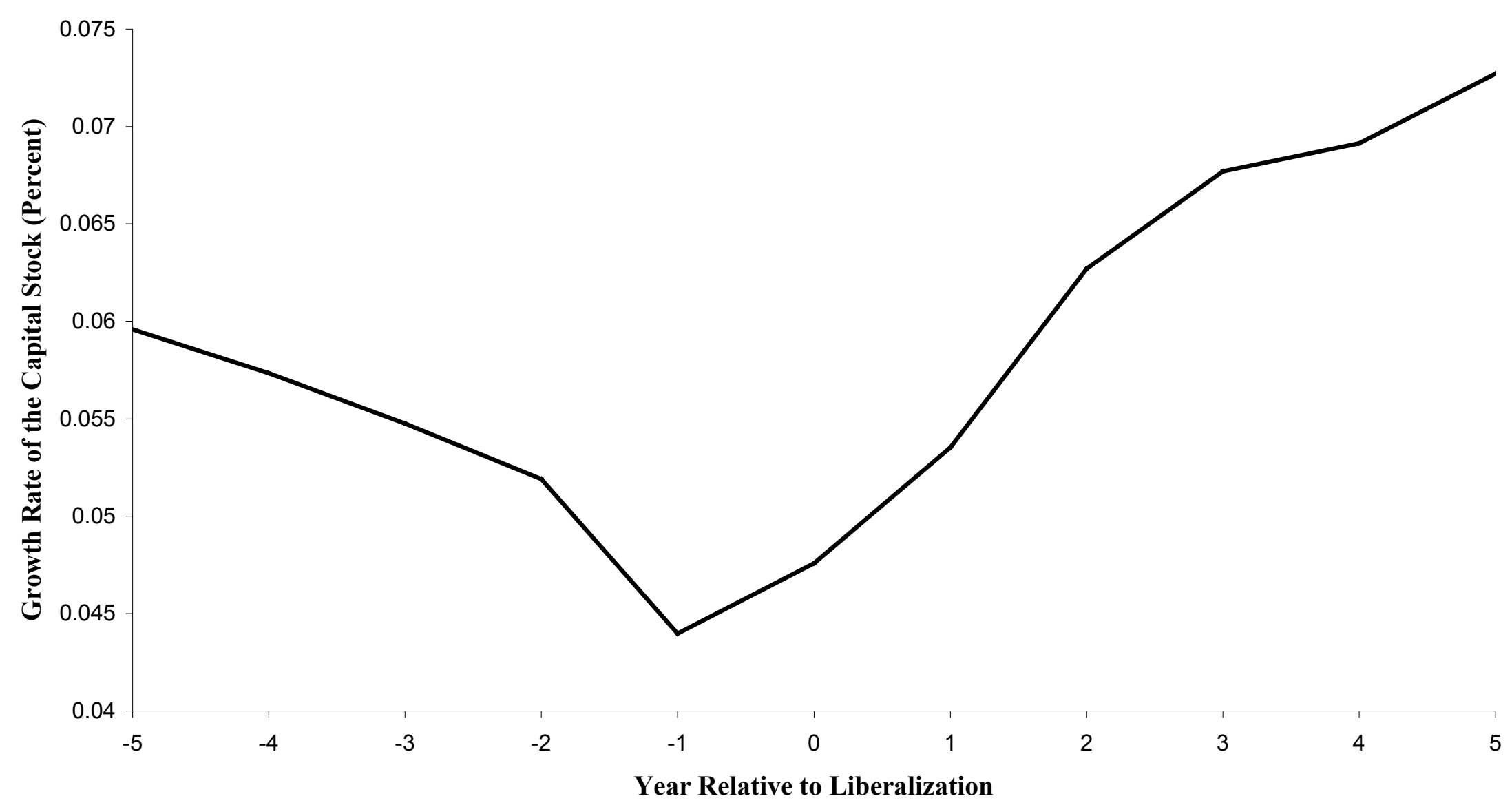

Figure 2. Investment Booms When Countries Liberalize the Capital Account . 


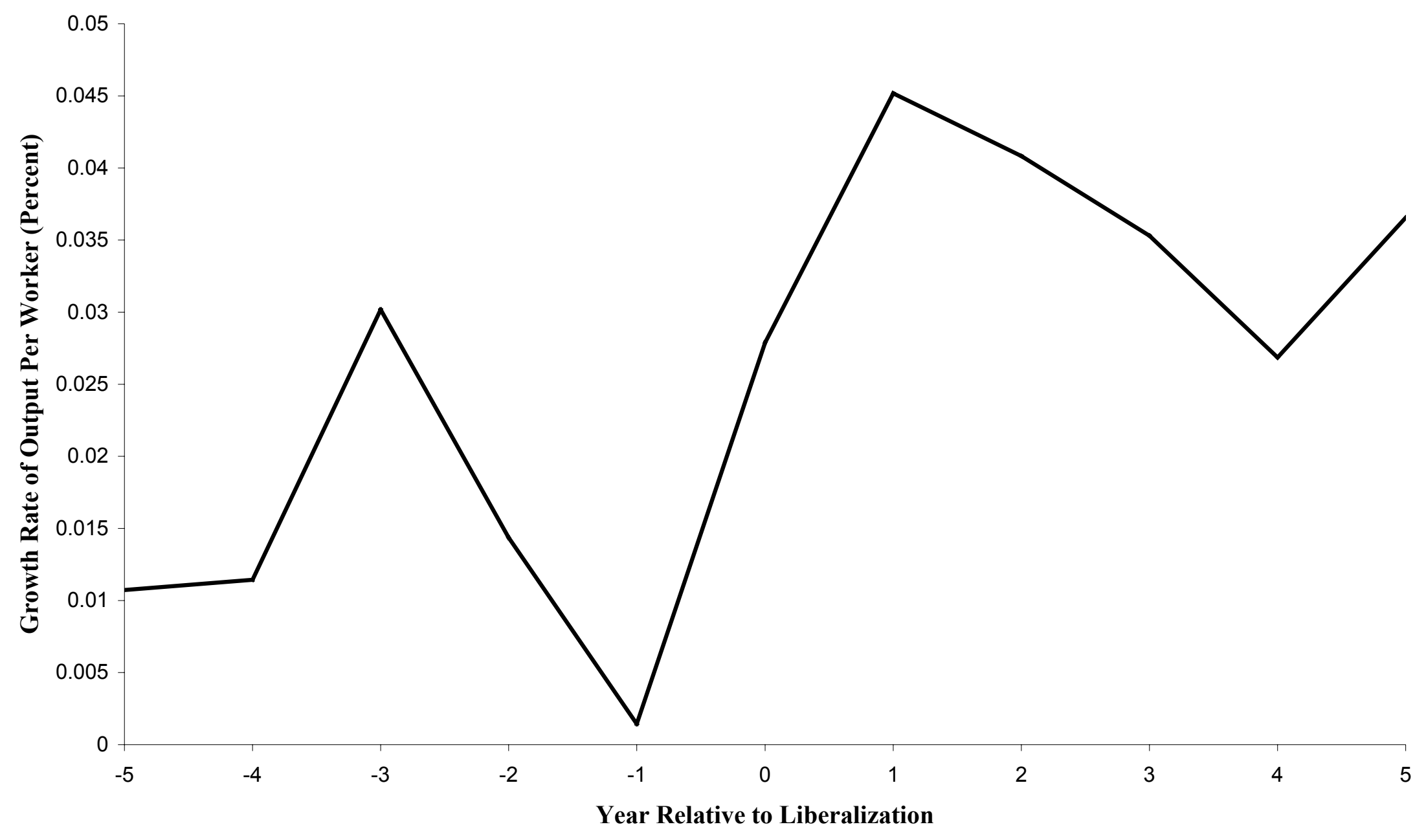

Figure 3. The Growth Rate of Output Per Worker Increases When Countries Liberalize 
Figure 4. Growth Also Increases Following Trade Liberalizations

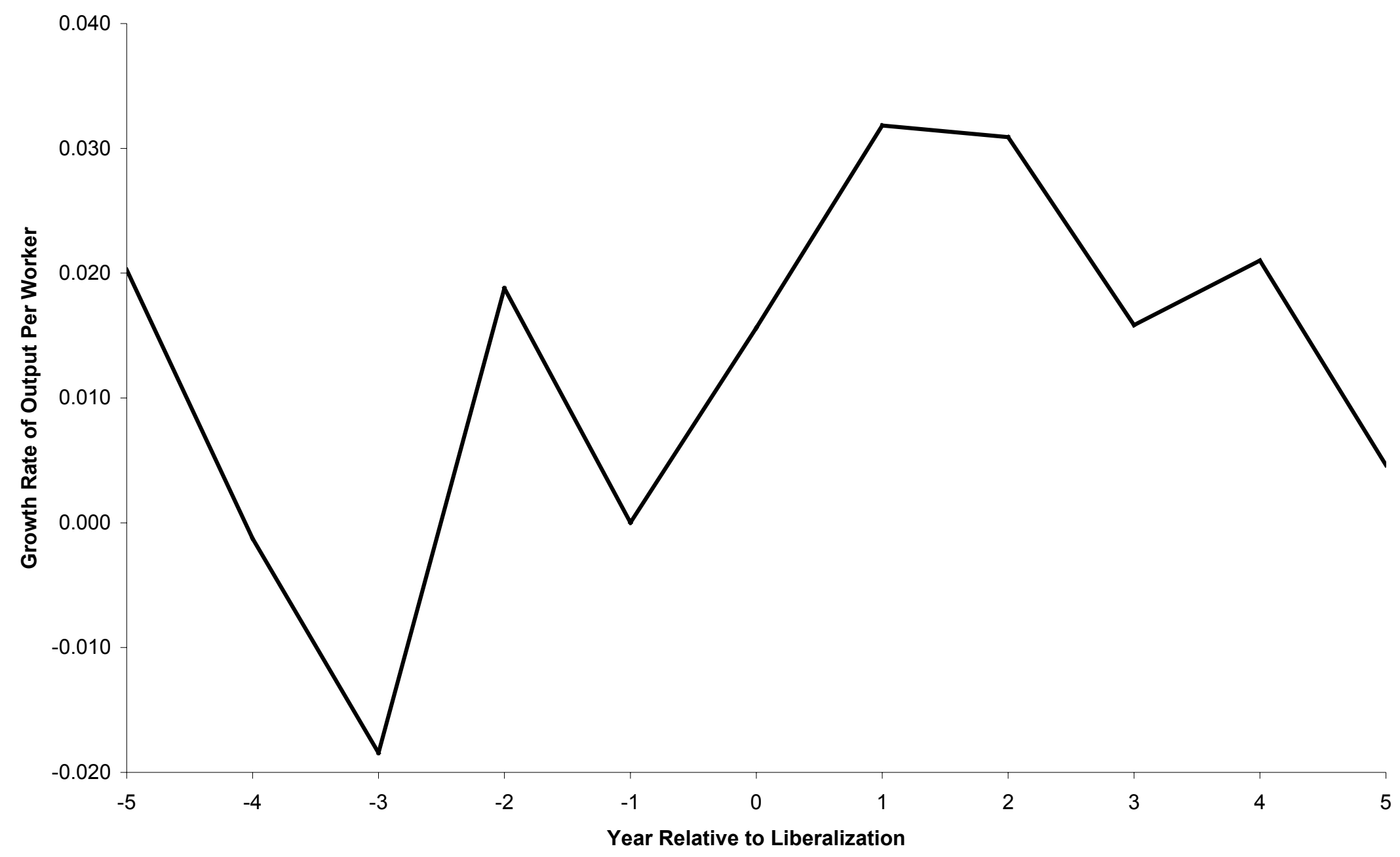


Figure 5. Growth Also Increases Following Inflation Stabilization Programs



